\title{
ACCEPTANCE OF PEOPLE WITH DISABILITIES AND THE PLACE OF RESIDENCE. POLISH EXPERIENCES
}

\author{
Zdzisław Kazanowski \\ University of Maria Curie-Skłodowska in Lublin, Poland \\ Agnieszka Żyta \\ University of Warmia and Mazury in Olsztyn, Poland
}

\begin{abstract}
The acceptance of people with disabilities is multidimensional and is sometimes analyzed concerning various factors. Both external (demographic) factors, e.g. age, gender, place of residence, type of education or occupation, and internal factors (e.g. level of intelligence, self-esteem, sense of coherence) can be taken into consideration. The study presents the results of an analysis of the relationship between the place of residence and the level of acceptance of people with disabilities. The study uses the Disability Acceptance Scale, which consists of 27 statements and is a tool to measure the level of acceptance of people with disabilities in three dimensions: (1) acceptance of support given to people with disabilities; (2) acceptance of inclusion of people with disabilities in the institutions of social life; (3) acceptance of competences of people with disabilities to function in social roles. The study involved 313 people living in south-eastern Poland, including 156 women (49.84\%) and 157 men (50.16\%) representing three types of residential settings: countryside, small town, and big city. The results of the research revealed that the respondents declared the highest level of acceptance concerning the inclusion of people with disabilities in the institutions of social life (dimension 2), while acceptance of their competence to function in social roles (dimension 3) was at the lowest level. Besides, statistically significant differences were observed between groups separated by place of residence in terms of the intensity of acceptance for the inclusion of people with disabilities in institutions of social life.
\end{abstract}

Keywords: acceptance, disability, place of residence.

\section{Introduction}

The level of acceptance of people with disabilities in society is an important condition for social inclusion. The contemporary approach to disability, based on the biopsychosocial concept of its causes, promoting equal rights of all citizens, eliminating marginalisation and social exclusion, and creating full access to social resources to ensure high quality of life for all, provides important premises for increasing the level of acceptance of this group of people. The construct of acceptance is heterogeneous, characterized by a variety of interpretations and multiple definitions. Furthermore, the literature 
Kazanowski \& Żyta, 2021. Acceptance of People with Disabilities and the Place of Residence. Polish Experiences

highlights the lack of a comprehensive and systematic framework for understanding the broader multifaceted construct of acceptance (Williams \& JanLynn, 2010). It is also important to remember that the acceptance of people with disabilities by non-disabled members of society is multidimensional and can be analyzed in terms of many factors: both external demographic and internal (Zasępa, Czabała \& Starzomska, 2005, Morin, Rivard, Crocker, Boursier \& Caron, 2013). One of the external factors influencing the level of acceptance is the place of residence of the surveyed people, which is not only a certain geographic-social-cultural space but also a place where certain values, norms, and patterns of behaviour essential for shaping identity and life choices are acquired. The place - depending on its size - can affect the individual, their interactions with others, their level of community involvement, their access to public facilities to varying degrees and extents. One of the most serious consequences of the increase in the number of inhabitants is the disappearance of direct interactions and the increase in anonymity, which indirectly may affect relations with other people or social attitudes, also towards people with disabilities. The present research project focuses on the search for relations between the acceptance of people with disabilities and the place of residence of the respondents.

\section{Acceptance of People with Disabilities and a Place-based Model - Theoretical Background}

Social psychology suggests that acceptance is probably one of the most important factors for people's well-being within a social context (DeWall \& Bushman, 2011). We consider social integration to be successful when the person with a disability is accepted as a full member of the society by other people (including peers, neighbours, co-workers etc.). Acceptance is thus an essential component of social integration (Vornholt, Uitdewilligen \& Nijhuis, 2013). Social acceptance is a prerequisite for the development of close relationships, for social inclusion and also for the weakening of negative stereotypes about people with disabilities. Besides, it is an essential condition for creating a climate of integration that goes beyond mere physical accessibility (Devine, 2004).

One of the elements influencing the attitudes towards people with disabilities and the level of their acceptance is the place of residence. The residential environment during childhood and adolescence is the primary area of primary socialisation, which is expressed by internalisation of certain values, norms, behavioural patterns and attitudes, which over time take the form of relatively stable attitudes. This environment is co-created by the family, preschool, school and local interactions. The place of residence varies in terms of 
the degree of homogeneity of the inhabitants, the level of urbanisation and industrialisation, and the size of the community. The differences between rural and urban areas are so great that the latter category is generally divided into large cities and medium and small towns. The latter creates an intermediate category between cities and villages, preserving many traditional patterns characteristic for rural life, but differing from it in terms of the number of inhabitants, which translates into the disappearance of direct interactions and the dissemination of urban life patterns (e.g. concerning leisure activities or household equipment and organisation) (Chodkowska \& Kazanowski, 2019).

J.S.Carter, S.K.Carter \& M.Corra (2016, p.272) suggest using "a placebased model that considers location a significant agent of socialization and producer of attitudes. This model is based on the work of classical scholars who emphasized the impact of place on viewpoints (Stouffer, 1955, Wirth, 1938). According to the place-based model, attitudes depend more on whether a person lives in certain locations rather than when a person lives in those locales." In the classical view, urban areas foster more cosmopolitan and progressive views, more tolerant attitudes towards minority and commonly marginalised groups. At the same time, secondary rather than primary relationships, of a more impersonal nature, predominate here. In the rural environment, by contrast, residents are less anonymous and more exposed to the judgements of others. Both non-standard behaviour and appearance may meet with less tolerance in the countryside (Carter et al. 2016, Dudak, 2019). The distinction between rural and urban environments appears important in certain cultural contexts (Magiati, Dockrell, \& Logotheti, 2002).

Research on attitudes towards people with disabilities is carried out in different cultural circles. S.Chen, L.Ma \& J.-X.Zhang (2011) conducted a study among Chinese students finding that those from rural areas have more negative attitudes compared to urban students. The student residential environment influenced people's implicit attitudes, while at the level of explicit attitudes, no differences were observed. In contrast, research among Greek pupils aged 9-12 has shown that those living in rural areas are more willing to play with children with special needs during school breaks. Furthermore, rural children were more aware of the social impact of physical difficulties (Magiati et al., 2002). Polish research shows a higher level of willingness to tolerate students with intellectual disabilities among young people living in large cities, while a higher level of willingness to support students with disabilities among rural residents (Chodkowska \& Kazanowski 2019). 
Kazanowski \& Żyta, 2021. Acceptance of People with Disabilities and the Place of Residence. Polish Experiences

\section{Methodology}

The aim of our study was cognitive and was to determine the level of acceptance of people with disabilities in different residential environments as expressed in three dimensions: approval of the support provided, support for the participation of people with disabilities in social life, and recognition of their competence in performing social roles. The designed diagnosis made it possible both to assess the differentiation of the level of acceptance itself (dependent variable) and to compare it in the context of the independent variable, which was the place of residence of people participating in the research. The main problem of the research was formulated in the form of the question: What is the level of acceptance of people with disabilities in terms of recognition of their support, approval of their participation in social life and respect for the competences required to perform social roles among people from different residential environments?

In the research, we used the diagnostic survey method and the questionnaire technique. We collected material for quantitative analyses aimed at achieving the planned goal. The survey questionnaire consisted of three parts: 1) the Acceptance of Persons with Disabilities Scale, 2) the Social Approval Questionnaire (KAS) and 3) Information about the people participating in the study. The Disability Acceptance Scale allows for the collection of research material which can then be analysed in three areas: 1- acceptance of the support provided to people with disabilities, 2 - acceptance of the inclusion of people with disabilities in institutions of social life and 3 - the expression of acceptance of the competence of people with disabilities to function in social roles.

Factor 1 contains 17 items explaining $12.68 \%$ of the variance in results.

It includes statements referring, among others, to the acceptance of giving priority in access to medical care and assistance, free participation in cultural events, dissemination of images of artists with disabilities, the need to remove obstacles to their mobility and access to public institutions, and regarding personal interest in their achievements.

Factor 2 contains 13 statements that explain $12.47 \%$ of the variance in results. It contains statements treating, among others, access of persons with disabilities to goods and services enabling full participation in social life, the right to education in a mainstream school, the right to marry, and access to medical care services.

Factor 3 contains 13 items explaining $11.24 \%$ of the variance in results.

It focuses, inter alia, on the acceptance of training and employment of persons with disabilities on the open labor market, their holding managerial positions, and assessing their ability to perform marital and parental roles (Kazanowski, 2019). 
The Social Approval Scale was used as a tool to monitor the level of social approval. As noted by J.J.Shaughnessy, E.B.Zechmeister \& J.S.Zechmeister (2002, p.182), "the quest for social approval may cause respondents not to answer truthfully, but according to an idea of what they should answer". The research of B. Weigl confirmed that "secondary school students display less stereotypical perception and less overt prejudice (which, however, is significantly correlated with the need for social approval: the greater the need for approval, the more favourable the image of others)." (Weigl, 1999, p.140). By controlling for the level of social approval, a serious source of distortion of the obtained research results can be avoided. Finally, after taking into account the KAS criterion (subjects with scores below 7 and above 21), the results of 41 subjects were rejected.

There were 313 participants in the study, including 156 (49.84\%) women and 157 (50.16\%) men. Detailed characteristics of people participating in the study are presented in Table 1.

Table 1 Sociodemographic Characteristics of People Participating in the Study

\begin{tabular}{|l|l|l|}
\hline \multicolumn{2}{|l|}{ Socio-demographic variables } & N \\
\hline SEX OF THE RESPONDENTS & 156 & 49,84 \\
\hline Female & 157 & 50,16 \\
\hline Male & \multicolumn{2}{l|}{} \\
\hline AGE OF THE RESPONDENTS*** & 97 & 30,99 \\
\hline 16 - 18 y. o & 107 & 35,14 \\
\hline 31 - 40 y. o. & 106 & 33,87 \\
\hline$>50$ y. o. & \multicolumn{2}{l|}{} \\
\hline PLACE OF RESIDENCE & 116 & 37,06 \\
\hline Rural & 93 & 29,71 \\
\hline Town & 104 & 33,23 \\
\hline City & \multicolumn{2}{l|}{} \\
\hline MOTHER'S EDUCATION & 45 & 14,38 \\
\hline Primary education & 96 & 30,67 \\
\hline Vocational education & 108 & 34,50 \\
\hline Secondary education & 64 & 20,45 \\
\hline Higher education & \multicolumn{2}{l|}{} \\
\hline FATHER'S EDUCATION & 50 & 15,97 \\
\hline Primary education & 126 & 40,26 \\
\hline Vocational education & 81 & 25,88 \\
\hline Secondary education & 51 & 16,29 \\
\hline Higher education & 5 & 1,60 \\
\hline No answer & 109 & 34,82 \\
\hline MOTHER'S EMPLOYMENT * & 142 & 45,37 \\
\hline She does not work &
\end{tabular}


Kazanowski \& Żyta, 2021. Acceptance of People with Disabilities and the Place of Residence. Polish Experiences

\begin{tabular}{|c|c|c|}
\hline No answer & 62 & 19,81 \\
\hline \multicolumn{3}{|l|}{ FATHER'S EMPLOYMENT* } \\
\hline He does not work & 66 & 21,09 \\
\hline He works & 179 & 57,19 \\
\hline No answer & 68 & 21,72 \\
\hline \multicolumn{3}{|l|}{ STRUCTURE OF THE FAMILY ENVIRONMENT ** } \\
\hline Nuclear family/Extended family & 279 & 87,14 \\
\hline Single-parent family & 34 & 10,86 \\
\hline \multicolumn{3}{|l|}{ Siblings } \\
\hline Yes & 247 & 78,91 \\
\hline No & 66 & 21,09 \\
\hline \multicolumn{3}{|l|}{ Persons with disabilities in family } \\
\hline Yes & 45 & 14,38 \\
\hline No & 267 & 85,30 \\
\hline No answer & 1 & 0,32 \\
\hline \multicolumn{3}{|c|}{ INTERACTION WITH PUPILS WITH DISABILITIES IN PRIMARY SCHOOL } \\
\hline Yes & 34 & 10,86 \\
\hline No & 269 & 85,94 \\
\hline No answer & 10 & 3,20 \\
\hline $\begin{array}{llllll}\text { CONTACTS WITH } & \text { PUPILS WITH } & \text { DISABILITIES II } \\
\text { SCHOOL } & & & & & \\
\end{array}$ & $\mathrm{LO}$ & ECONDARY \\
\hline Yes & 20 & 6,39 \\
\hline No & 249 & 79,55 \\
\hline No answer & 44 & 14,06 \\
\hline \multicolumn{3}{|c|}{ INTERACTION WITH STUDENTS WITH DISABILITIES IN SECONDARY SCHOOL } \\
\hline Yes & 24 & 7,67 \\
\hline No & 285 & 91,05 \\
\hline No answer & 4 & 1,28 \\
\hline \multicolumn{3}{|c|}{ CONTACTS WITH PEOPLE WITH DISABILITIES IN THE COMMUNITY } \\
\hline Yes & 68 & 21,73 \\
\hline No & 244 & 77,95 \\
\hline No answer & 1 & 0,32 \\
\hline
\end{tabular}

* for the second and third age groups, it is the period during the developmental age

** in the case of the second and third age group, it is the family of origin in which the respondents were brought up at the developmental age

*** to provide a broader demographic context for the research findings presented in the study, in the selection of the study group we planned a social representation comprising three age categories.

Probabilistic stratified sampling was used in the study. During meetings held in selected classrooms in schools, students were asked to participate in the study and each student was given three copies of the questionnaire (one for the student and two for other adults living together) to complete at home. Analysis of variance and Tukey's RIR test were used in the statistical analysis of the study results. 


\section{Research Results}

The analysis of the research results compared the intensity of acceptance declared by the respondents relating to people with disabilities by place of residence. The structure of the measured acceptance was also taken into account, directing attention to the analysis of research results relating to the three areas of the examined dependent variable. Analysis of these four variables connected with acceptance of disabled people considering the place of the place of residence are presented in Table 2.

Table 2 Results of the Analysis of Acceptance of Persons with Disabilities Considering the Place of Residence

\begin{tabular}{|l|c|c|c|c|c|c|c|c|}
\hline \multirow{2}{*}{$\begin{array}{l}\text { Variable: Acceptance of } \\
\text { disabled people }\end{array}$} & \multicolumn{2}{|c|}{$\begin{array}{c}\text { Place of } \\
\text { residence - } \\
\text { rural }\end{array}$} & \multicolumn{2}{|c|}{$\begin{array}{c}\text { Place of } \\
\text { residence - } \\
\text { small town }\end{array}$} & \multicolumn{2}{|c|}{$\begin{array}{c}\text { Place of } \\
\text { residence - } \\
\text { large city }\end{array}$} & F & P \\
\cline { 2 - 9 } & $M$ & $S D$ & $M$ & $S D$ & $M$ & $S D$ & \\
\hline $\begin{array}{l}\text { Factor 1: Accepting the } \\
\text { support given to people } \\
\text { with disabilities }\end{array}$ & 3,52 & 0,56 & 3,53 & 0,50 & 3,63 & 0,68 & 1,060 & 0,348 \\
\hline $\begin{array}{l}\text { Factor 2: acceptance of } \\
\text { the inclusion of people } \\
\text { with disabilities in } \\
\text { institutions of social life }\end{array}$ & 3,95 & 0,68 & 3,88 & 0,75 & $\mathbf{4 , 1 2}$ & 0,65 & 3,170 & $0,043^{1}$ \\
\hline $\begin{array}{l}\text { Factor 3: Accepting the } \\
\text { competence of people } \\
\text { with disabilities to } \\
\text { function in social roles }\end{array}$ & 3,26 & 0,55 & 3,27 & 0,61 & 3,37 & 0,65 & 1,076 & 0,342 \\
\hline
\end{tabular}

${ }^{1}$ Statistically significant differences between people living in a small town and those living in a big city $(\mathrm{p}=0.039)$

Analyzing the data in Table 2 it can be noted that there is a statistically significant difference in the acceptance of the inclusion of people with disabilities in institutions of social life between people who live in a small town and those who live in big cities ( $\mathrm{p}=0.039$ ). It is worth stressing that people living in small towns are less accepting of the inclusion of people with disabilities in institutions of social life $(\mathrm{M}=3.88)$. It is also worth noting that in all selected groups, the lowest results refer to the acceptance of fulfilling social roles by people with disabilities and the highest to the acceptance of the inclusion of persons with disabilities in institutions of social life. It can also be noticed that respondents living in big cities declare a higher general level of acceptance for people with disabilities $(M=3.71)$ than respondents living in small towns $(\mathrm{M}=3.56)$ or villages $(\mathrm{M}=3.58)$. On the other hand, if people living in cities were 
Kazanowski \& Żyta, 2021. Acceptance of People with Disabilities and the Place of Residence. Polish Experiences

to be combined into one group, it would turn out that the general level of acceptance of people with disabilities among respondents living in cities $(M=3.63)$ is higher than among respondents living in rural areas $(M=3.58)$. Although the differences, in this case, do not reach a statistically significant value, they encourage us to carry out more detailed analyses and search for intergroup differences also in terms of individual dimensions of acceptance at the item level of the questionnaire used.

The analysis of the acceptance of the support provided to people with disabilities in the opinions of people representing different categories of living environment is presented in Table 3.

\section{Table 3 Results of the Analysis of the Acceptance of Support Provided to People with Disabilities according to the Place of Residence}

\begin{tabular}{|l|c|c|c|c|c|c|c|c|}
\hline \multirow{2}{*}{$\begin{array}{l}\text { Factor 1: Accepting the } \\
\text { support given to people with } \\
\text { disabilities }\end{array}$} & $\begin{array}{l}\text { Place of } \\
\text { residence - } \\
\text { rural }\end{array}$ & \multicolumn{2}{|l|}{$\begin{array}{l}\text { Place of } \\
\text { residence - } \\
\text { small town }\end{array}$} & \multicolumn{2}{|c|}{$\begin{array}{c}\text { Place of } \\
\text { residence - } \\
\text { large city }\end{array}$} & F & p \\
\cline { 2 - 8 } & $M$ & $S D$ & $M$ & $S D$ & $M$ & $S D$ & \\
\hline $\begin{array}{l}\text { Perosns with disabilities } \\
\text { create outstanding works of } \\
\text { art }\end{array}$ & 3,70 & 0,94 & 3,60 & 1,03 & 3,73 & 1,01 & 0,442 & 0,643 \\
\hline $\begin{array}{l}\text { I would donate money to } \\
\text { support people with } \\
\text { disabilities }\end{array}$ & 3,12 & 1,01 & 3,54 & 0,88 & 3,18 & 1,12 & 4,876 & $0,008^{2}$ \\
\hline $\begin{array}{l}\text { Lack of special facilities for } \\
\text { the disabled in schools } \\
\text { reduces the number of } \\
\text { students with disabilities in } \\
\text { mainstream institutions }\end{array}$ & 3,58 & 0,99 & 3,65 & 0,99 & 3,76 & 1,11 & 0,868 & 0,421 \\
\hline $\begin{array}{l}\text { I would love to go to a } \\
\text { theatre performance with } \\
\text { people with disabilities }\end{array}$ & 3,41 & 1,00 & 3,52 & 1,06 & 3,66 & 1,06 & 1,601 & 0,203 \\
\hline $\begin{array}{l}\text { People with disabilities } \\
\text { should have priority in } \\
\text { access to medical care and } \\
\text { assistance }\end{array}$ & 3,67 & 1,09 & 3,51 & 0,98 & 3,52 & 1,18 & 0,787 & 0,456 \\
\hline $\begin{array}{l}\text { Difficulties in access to } \\
\text { public institutions for } \\
\text { people with disabilities are } \\
\text { the responsibility of non- } \\
\text { disabled people }\end{array}$ & 3,72 & 0,94 & 3,70 & 1,00 & 3,84 & 1,11 & 0,563 & 0,570 \\
\hline $\begin{array}{l}\text { People with disabilities } \\
\text { should be able to participate } \\
\text { in cultural events free of } \\
\text { charge }\end{array}$ & 3,15 & 1,10 & 3,04 & 1,07 & 3,39 & 1,14 & 2,690 & 0,069 \\
\hline
\end{tabular}


SOCIETY. INTEGRATION. EDUCATION

Proceedings of the International Scientific Conference. Volume III, May $28^{\text {th }}-29^{\text {th }}$, 2021. 85-98

\begin{tabular}{|l|l|l|l|l|l|l|l|l|}
\hline $\begin{array}{l}\text { It is necessary to include images of } \\
\text { people with disabilities in the } \\
\text { school programme }\end{array}$ & 3,44 & 0,91 & 3,49 & 0,87 & 3,53 & 1,01 & 0,257 & 0,774 \\
\hline $\begin{array}{l}\text { The achievements of people with } \\
\text { disabilities are important for the } \\
\text { development of society }\end{array}$ & 3,53 & 0,80 & 3,29 & 1,08 & 3,69 & 1,02 & 4,288 & $0,015^{3}$ \\
\hline $\begin{array}{l}\text { Society has a duty to eliminate } \\
\text { obstacles that hinder the free } \\
\text { movement of persons with } \\
\text { disabilities }\end{array}$ & 4,14 & 0,98 & 4,09 & 0,96 & 4,10 & 1,18 & 0,075 & 0,928 \\
\hline $\begin{array}{l}\text { Places where you can see the } \\
\text { achievements of persons with } \\
\text { disabilities are needed }\end{array}$ & 3,27 & 0,90 & 3,42 & 0,94 & 3,49 & 1,17 & 1,412 & 0,245 \\
\hline
\end{tabular}

${ }^{2}$ Statistically significant differences between those living in a rural area and a small town $(\mathrm{p}=$ $0.009)$ and in a small town and a large city $(\mathrm{p}=0.038)$.

${ }^{3}$ Statistically significant differences between adolescents living in a small town and in a large city $(\mathrm{p}=0.010)$.

A detailed analysis of the acceptance of support provided to people with disabilities revealed statistically significant differences in opinions between people representing different categories of a living environment. It was found that people living in small towns are characterized by a significantly higher level of readiness to provide financial support to people with disabilities $(p=0.008)$ than those living in rural areas and big cities, which can be interpreted as understanding the necessity of incurring higher costs related to satisfying their needs. Although the value of the mean $(\mathrm{M}=3.54)$ does not entitle to demonstrate a high intensity of this characteristic, it can be considered an important component for the acceptance of support provided to people with disabilities by this group of respondents.

A statistically significant difference also occurred concerning the evaluation of the achievements of people with disabilities $(p=0.015)$. Recognizing the achievements of people with disabilities as important for the development of society is characteristic of residents of large cities $(M=3.69)$. This result clearly corresponds to the belief in the existence of outstanding achievements among people with disabilities in the area of artistic creativity $(M=3.73)$. Respect for the effort made by people with disabilities and a positive opinion about its results, distinguish the acceptance of inhabitants of big cities concerning providing support to these people in comparison to inhabitants of small cities $(\mathrm{p}=0.010)$.

Analysis of the acceptance of the inclusion of people with disabilities in institutions of social life according to the place of residences is described in Table 4. 
Kazanowski \& Żyta, 2021. Acceptance of People with Disabilities and the Place of Residence. Polish Experiences

Table 4 Results of the Analysis of the Acceptance of the Inclusion of People with Disabilities in Institutions of Social Life according to the Place of Residence

\begin{tabular}{|c|c|c|c|c|c|c|c|c|}
\hline \multirow{2}{*}{$\begin{array}{l}\text { Factor 2: acceptance of the } \\
\text { inclusion of people with } \\
\text { disabilities in institutions of } \\
\text { social life }\end{array}$} & \multicolumn{2}{|c|}{$\begin{array}{l}\text { Place of } \\
\text { residence - } \\
\text { rural }\end{array}$} & \multicolumn{2}{|c|}{$\begin{array}{l}\text { Place of } \\
\text { residence - } \\
\text { small town }\end{array}$} & \multicolumn{2}{|c|}{$\begin{array}{l}\text { Place of } \\
\text { residence - } \\
\text { large city }\end{array}$} & \multirow[t]{2}{*}{$\mathrm{F}$} & \multirow[t]{2}{*}{$\mathrm{p}$} \\
\hline & $M$ & $S D$ & $M$ & $S D$ & $M$ & $S D$ & & \\
\hline $\begin{array}{l}\text { Achievements of people } \\
\text { with disabilities deserve to } \\
\text { be made public }\end{array}$ & 4,10 & 1,11 & 3,98 & 1,22 & 4,47 & 0,81 & 5,959 & $0,003^{4}$ \\
\hline $\begin{array}{l}\text { People with disabilities } \\
\text { should get married }\end{array}$ & 3,87 & 1,16 & 4,01 & 1,13 & 4,20 & 1,00 & 2,495 & 0,084 \\
\hline $\begin{array}{l}\text { People with disabilities } \\
\text { should be guaranteed access } \\
\text { to goods and services } \\
\text { enabling full participation } \\
\text { in socjety. }\end{array}$ & 4,20 & 0,84 & 4,11 & 0,93 & 4,30 & 0,82 & 1,211 & 0,299 \\
\hline $\begin{array}{l}\text { Students without } \\
\text { disabilities should interact } \\
\text { with their peers with } \\
\text { disabilities at school }\end{array}$ & 4,28 & 0,94 & 4,05 & 1,16 & 4,26 & 1,11 & 1,330 & 0,266 \\
\hline $\begin{array}{l}\text { People with disabilities } \\
\text { should enjoy the full right } \\
\text { to education in mainstream } \\
\text { schools }\end{array}$ & 3,85 & 1,07 & 3,76 & 0,99 & 4,10 & 0,98 & 2,889 & 0,057 \\
\hline $\begin{array}{l}\text { People with disabilities } \\
\text { should show their feelings } \\
\text { in public }\end{array}$ & 3,72 & 1,27 & 3,75 & 1,10 & 4,02 & 1,13 & 2,096 & 0,125 \\
\hline $\begin{array}{l}\text { People with disabilities } \\
\text { limit others' access to health } \\
\text { care services* }\end{array}$ & 3,66 & 1,01 & 3,48 & 1,07 & 3,49 & 1,27 & 0,907 & 0,405 \\
\hline
\end{tabular}

${ }^{4}$ Statistically significant differences between those living in a rural area and in a large city $(p=0.027)$ and between those living in a small town and in a large city $(p=0.003)$.

When analyzing acceptance concerning the inclusion of people with disabilities in institutions of social life, a statistically significant difference was found concerning the need to disseminate the achievements of people with disabilities $(\mathrm{p}=0.003)$. People living in a big city represent a significantly higher level of belief in the need to disseminate the achievements of people with disabilities $(\mathrm{M}=4.47)$ compared to groups of people from other residential environments.

The last factor analysed in our research concerned the acceptance of the competences of people with disabilities to function in social roles and is presented in Table 5. 
SOCIETY. INTEGRATION. EDUCATION

Proceedings of the International Scientific Conference. Volume III, May $28^{\text {th }}-29^{\text {th }}$, 2021. 85-98

Table 5 Results of the Analysis of the Acceptance of the Competences of People with Disabilities to Function in Social Roles according to the Place of Residence

\begin{tabular}{|l|c|c|c|c|c|c|c|c|}
\hline $\begin{array}{l}\text { Factor 3: Accepting the } \\
\text { competence of people with } \\
\text { disabilities to function in } \\
\text { social roles }\end{array}$ & $\begin{array}{c}\text { Place of } \\
\text { residence - } \\
\text { rural }\end{array}$ & \multicolumn{2}{|c|}{$\begin{array}{c}\text { Place of } \\
\text { residence - } \\
\text { small town }\end{array}$} & \multicolumn{2}{|c|}{$\begin{array}{c}\text { Place of } \\
\text { residence - } \\
\text { large city }\end{array}$} & F & p \\
\cline { 2 - 9 } & $M$ & $S D$ & $M$ & $S D$ & $M$ & $S D$ & \\
\hline $\begin{array}{l}\text { Students with disabilities } \\
\text { should have the opportunity } \\
\text { to be educated in any } \\
\text { school. }\end{array}$ & 3,91 & 1,12 & 3,75 & 1,18 & 4,00 & 1,07 & 1,225 & 0,295 \\
\hline $\begin{array}{l}\text { People with disabilities are } \\
\text { less productive workers } \\
\text { than non-disabled people* }\end{array}$ & 3,15 & 0,96 & 3,19 & 1,20 & 3,56 & 1,20 & 4,285 & $0,015^{5}$ \\
\hline $\begin{array}{l}\text { A parent with a disability is } \\
\text { able to provide their child } \\
\text { with the same upbringing } \\
\text { conditions as a non- } \\
\text { disabled parent, }\end{array}$ & 3,12 & 1,11 & 3,24 & 1,17 & 3,27 & 1,32 & 0,466 & 0,628 \\
\hline $\begin{array}{l}\text { I could cooperate with a } \\
\text { person with a disability in } \\
\text { an important task }\end{array}$ & 3,79 & 0,93 & 3,70 & 0,94 & 3,63 & 1,07 & 0,727 & 0,484 \\
\hline $\begin{array}{l}\text { Every institution should } \\
\text { employ people with } \\
\text { disabilities }\end{array}$ & 2,95 & 1,01 & 2,87 & 1,00 & 2,74 & 1,02 & 1,169 & 0,312 \\
\hline $\begin{array}{l}\text { I would support the } \\
\text { candidacy of a person with } \\
\text { a disability for a } \\
\text { management position }\end{array}$ & 3,34 & 0,98 & 3,34 & 0,94 & 3,51 & 1,04 & 1,028 & 0,359 \\
\hline $\begin{array}{l}\text { Marriages of persons with } \\
\text { disabilities do not differ } \\
\text { from marriages of persons } \\
\text { without disabilities }\end{array}$ & 3,39 & 1,09 & 3,54 & 1,11 & 3,38 & 1,14 & 0,602 & 0,548 \\
\hline $\begin{array}{l}\text { Being able to choose a future } \\
\text { employee, it is better to hire a } \\
\text { disabled person than a non-disabled } \\
\text { person }\end{array}$ & 2,67 & 0,88 & 2,74 & 0,93 & 2,89 & 0,97 & 1,613 & 0,201 \\
\hline $\begin{array}{l}\text { People with disabilities have great } \\
\text { potential to lead social } \\
\text { organisations }\end{array}$ & 3,01 & 0,91 & 3,09 & 0,76 & 3,35 & 0,97 & 4,217 & $0,016^{6}$ \\
\hline
\end{tabular}

${ }^{5}$ Statistically significant differences between those living in rural areas and in a large city ( $\mathrm{p}=0.018)$.

${ }^{6}$ Statistically significant differences between those living in rural areas and in a large city ( $\mathrm{p}=0.014)$. 
Kazanowski \& Żyta, 2021. Acceptance of People with Disabilities and the Place of Residence. Polish Experiences

The analysis of the acceptance of the competence of people with disabilities to function in social roles revealed statistically significant differences between the surveyed groups regarding the assessment of the productivity of people with disabilities $(\mathrm{p}=0.015)$ and their ability to lead social organizations $(\mathrm{p}=0.016)$. The greatest differences were between people living in rural areas and big cities, with those living in big cities assessing more positively the potential of people with disabilities to lead community organizations and those living in rural areas assessing more positively their efficiency. Thus, there was an ambivalence of evaluation in this dimension, which is a typical phenomenon considering attitudes towards people with disabilities.

\section{Discussion and Conclusions}

Differences in social and familial relationships, rhythms of life, and interaction with the natural environment and the wider community may be relevant (Magiati et al., 2002).

The level of acceptance relating to people with disabilities shows variation according to the place of residence of the survey participants, which means that it can be an important explanatory variable for difficulties in community integration. Our research confirms that the level of acceptance of people with disabilities among people living in big cities is usually higher than among people living in rural areas or small towns and reaches a significantly higher level of support for their participation in society. This seems to confirm both classical approaches to the influence of the urban environment on less exclusionary attitudes towards marginalized groups (Carter et al, 2016), as well as previous Polish or Chinese research (Chen et al., 2011, Chodkowska \& Kazanowski, 2019). On the other hand, other studies report more positive attitudes towards students with disabilities among children living in rural environments (Gash \& Coffey 1995, Magiati et al., 2002). This may suggest that, in addition to place of residence (number of inhabitants living in a given place, type of relations prevailing in a given environment, access to public facilities), the cultural context plays an important role. Despite increasing globalization, certain cultural differences (e.g. rooted in history or the dominant religion) may influence the differences in results between countries.

The general level of acceptance of people with disabilities is not high. Most respondents' answers indicate an average level of approval for providing support to people with disabilities, their participation in social life, and the recognition of their competencies.

The place of residence differentiated to the greatest extent the respondents' views on the inclusion of people with disabilities in institutions of social life. Although all surveyed groups obtained the highest level of acceptance in this 
respect, people living in a big city dominated over others. Especially their conviction that the achievements of people with disabilities deserve to be made public may have determined this advantage.

The lowest level of acceptance in all groups was found concerning the assessment of the social competence of people with disabilities. In this area, detailed differences occurred in comparisons between people living in the countryside and a big city, revealing the possibility of achieving a similar level of acceptance based on beliefs concerning different aspects of the analyzed issue.

The level of acceptance of support provided to people with disabilities can also be regarded as average and similar in all surveyed groups, and detailed results do not clearly indicate any of the groups as representing its higher level.

The results of our research suggest that it is worth using their achievements in developing acceptance towards people with disabilities. Presenting the results of self-activity of people with disabilities may in this case turn out to be more effective than focusing on limitations and discovering barriers to taking up activity and meeting needs. It also seems necessary to continue research and to try to explain the differences in the level of acceptance of people with disabilities based on the place of residence.

\section{References}

Carter, J.S., Carter, S.K., \& Corra, M. (2016). The significance of place: The impact of urban and regional residence on gender-role attitudes. Sociological Focus, 49(4), 271-285.

Chen, S., Ma, L., Zhang, J.-X. (2011). Chinese Undergraduates' Explicit and Implicit Attitudes Toward Persons With Disabilities. Rehabilitation Counseling Bulletin, 55(1), 38-45.

Chodkowska, M., Kazanowski, Z. (2019). Gotowość młodzieży do integracji szkolnej z uczniem z niepetnosprawnościa intelektualna. Lublin: Wyd. UMCS

Devine, M.A. (2004). "Being a 'Doer' Instead of a 'Viewer"': The Role of Inclusive Leisure Contexts in Determining Social Acceptance for People with Disabilities. Journal of Leisure Research , 36 (2), 137-159.

DeWall, C.N., Bushman, B.J. (2011). Social acceptance and rejection: the sweet and the bitter. Current Directions in Psychological Science, 20(4), 256-60.

Dudak, A. (2019). Mężczyźni w zawodach sfeminizowanych - funkcjonujące stereotypy i ich konsekwencje w percepcji studentów. Annales Universitatis Mariae Curie-Skłodowska, Vol. XXXII (4), 217-230.

Gash, H., \& Coffey, D. (1995). Influences on attitudes towards children with mental handicap. European Journal of Special Needs Education, 10, 1 - 16.

Kazanowski, Z. (2019). Wielowymiarowość postaw wobec integracji społecznej osób z niepełnosprawnością. Edukacja-Technika-Informatyka, 1 (27), 243-248.

Magiati, I., Dockrell, J.E., Logotheti, A.-E. (2002). Young children's understanding of disabilities: the influence of development, context, and cognition. Applied Developmental Psychology, 23, 409 - 430 
Kazanowski \& Żyta, 2021. Acceptance of People with Disabilities and the Place of Residence.

Polish Experiences

Morin, D., Rivard, M., Crocker, A.G., Boursier, C.P. \& Caron, J. (2013). Public attitudes towards intellectual disability: a multidimensional perspective. Journal of Intellectual Disability Research, 57, part 3, 279-292. DOI: 10.1111/jir.12008

Shaughnessy, J.J., Zechmeister, E.B., Zechmeister, J.S. (2002). Metody badawcze w psychologii. Gdańsk: GWP.

Stouffer, S. (1955). Communism, Conformity, and Civil Liberties. New York: Doubleday

Vornholt K., Uitdewilligen S., Nijhuis, F.J.N. (2013). Factors Affecting the Acceptance of People with Disabilities at Work: A Literature Review. Journal of Occupational Rehabilitation, 23 (4), 463-475.

Weigl, B. (1999). Stereotypy i uprzedzenia etniczne u dzieci i młodzieży. Studium empiryczne. Warszawa: Wydawnictwo Instytutu Psychologii PAN.

Williams, J.C., JayLynn, S. (2010). Acceptance: An Historical and Conceptual Review. Imagination Cognition and Personality, 30(1), 5-56.

Wirth, L. (1938). Urbanism as a Way of Life. The American Journal of Sociology, 44(1), 1-24.

Zasępa, E., Czabała, C., Starzomska, M. (2005). Postawy wobec niepełnosprawności i osób niepełnosprawnych. Człowiek Niepetnosprawność Społeczeństwo, 1, 23-36 